\title{
Potensi Etnomedicine Daun Ubi Jalar Ungu (Ipomoea batatas L. Poir) dan Daun Ubi Jalar Putih (Ipomoea batatas L.) Sebagai Obat Demam Berdarah di Sleman DIY
}

\author{
Yuliana Prasetyaningsih *, Novita Sari, Hieronymus Rayi Prasetya, Rika Wulandari, Visensa Gerosa Naer
}

\begin{abstract}
Pendahuluan: Kearifan lokal, pengobatan tradisonal, dan pengetahuan etnobotani perlu dipelajari dan dikembangkan. Salah satu masalah yang masih sering terjadi pada masyarakat adalah munculnya penyakit demam berdarah yang disebabkan nyamuk Aedes Aegypti. Demam Berdarah Dengue merupakan penyakit yang ditakuti karena menurunkan konsentrasi trombosit ke tingkat rendah (trombositopenia) dan dapat menyebabkan perdarahan. Jumlah sel trombosit yang rendah, harus segera ditingkatkan untuk menghindari terjadinya syok. Secara empiris, masyarakat menggunakan air rebusan daun ubi jalar pada kasus-kasus DBD (Demam Berdarah Dengue) dan menunjukkan perbaikan. Penelitian ini bertujuan untuk mengetahui potensi etnomedicine daun ubi jalar ungu (ipomoea batatas I. poir) sebagai obat demam berdarah di wilayah Sleman, DIY. Selain itu juga untuk mengetahui persentase peningkatan jumlah trombosit pada Tikus Putih (Rattus norvegicus) dengan pemberian infusa Daun Ubi Jalar Ungu dan ubi jalar putih (Ipomoea batatas .L)
\end{abstract}

Jenis penelitian: True experimental dengan rancangan penelitian pretest dan post test with control group design. Penelitian ini menggunakan 35 tikus putih jantan yang dibagi dalam 7 kelompok perlakuan infusa daun ubi jalar ungu yaitu kelompok kontrol, kelompok dosis ringan, kelompok dosis sedang dan kelompok dosis berat untuk masing-masing infusa daun ubi jalar. Tikus diturunkan jumlah trombositnya melalui mekanisme kerusakan limpa dengan induksi anilin secara intravena. Setelah 24 jam penginduksian, hewan coba diberi perlakuan sesuai kelompok. Semua kelompok dihitung jumlah trombositnya sebelum dan sesudah perlakuan. Data yang diperoleh dari hasil penelitian dianalisis secara deskriptif yang disajikan dalam bentuk tabel dan narasi.

Hasil penelitian: Terjadi peningkatan jumlah trombosit pada kelompok kontrol sebanyak $43 \%$. Pada kelompok infusa daun ubi jalar ungu dosis ringan tidak ada peningkatan, kelompok dosis sedang meningkat sebesar 94\%, dan kelompok dosis tinggi diperoleh peningkatan sebesar $224 \%$. Pada kelompok infusa dun ubi jalar putih terdapat peningkatan pada dosis tinggi yaitu $7,2 \mathrm{ml} / 200 \mathrm{gr} \mathrm{BB}$ atau $26,46 \%$. Hasil uji statistik menunjukkan bahwa pemberian infusa daun ubi jalar putih pada pre test dan post test memiliki perbedaan yang bermakna dengan nilai $p$ value 0,023 . Sedangkan pemberian infusa daun ubi jalar ungu sebelum dan sesudah perlakuan tidak memiliki perbedaan secara bermakna yang ditunjukkan dengan nilai $p$ value 0,550 .

Afiliasi Penulis

Prodi D3 Analis Kesehatan

STIKes Guna Bangsa Yogyakarta

Korespondensi kepada

Y Prasetyaningsih

yulianaprasetya@gmail.com
Kesimpulan: Infusa daun ubi jalar ungu mampu meningkatkan jumlah trombosit yang lebih banyak dibandingkan dengan infusa daun ubi jalar putih. Infusa daun ubi jalar ungu dan ubi jalar putih memiliki potensi etnomedicine sebagai obat demam berdarah di Sleman, DIY.

Kata Kunci: Ipomoea batatas, etnomedicine, tikus putih, Trombosit, Demam Berdarah 


\section{Pendahuluan}

Indonesia merupakan wilayah kekayaan biodiversitas dunia terbesar kedua, termasuk kekayaan ragam tumbuhan obat dan ribuan spesies sudah digunakan masyarakat. Berbagai daerah memanfaatkan tumbuhan sebagai bahan etnomedisin dengan keunikan ramuan dan cara penyajian yang menunjukkan tingginya pengetahuan etnis lokal tentang tumbuhan obat. Pengetahuan tentang tumbuhan obat merupakan warisan budaya bangsa turun temurun yang pewarisannya perlu mendapat perhatian [7].

Pengetahuan etnobotani tradisional penting pemanfaatannya untuk riset farmasi dan penemuan obat baru. Selain itu juga penting untuk memberikan informasi keberlanjutan industri tanaman obat serta konservasi habitat sumberdaya hutan untuk mencatat tradisi endogenus dan kekayaan warisan [5].

Kemajuan teknologi dan ilmu pengetahuan ternyata tidak mampu begitu saja menghilangkan arti pengobatan tradisional. Oleh karena itu salah satu pengobatan alternatif yang dilakukan adalah meningkatkan penggunaan tumbuhan berkhasiat obat di kalangan masyarakat. Kearifan lokal, pengobatan tradisonal, dan pengetahuan etnobotani perlu dipelajari dan dikembangkan [8].

Salah satu masalah yang masih sering terjadi pada masyarakat adalah munculnya penyakit demam berdarah yang disebabkan oleh inang nyamuk Aedes Aegypti. Penyakit demam berdarah dapat mewabah sehingga meresahkan masyarakat, dimana penyakit ini dapat menyerang semua usia mulai dari balita sampai usia dengan aktivitas tinggi [3]

Demam berdarah atau Demam Berdarah Dengue adalah penyakit yang ditemukan di daerah tropis. Demam berdarah disebarkan kepada manusia oleh nyamuk Aedes aegypti. Pendarahan dan syok yang terjadi pada penyakit ini menyebabkan angka kematian yang cukup tinggi. Penyakit Demam Berdarah menunjukkan demam yang lebih tinggi, pendarahan, trombositopenia, dan hemokonsentrasi [1].

Trombositopenia adalah penurunan jumlah trombosit menjadi $<100.000 / \mu l$. Trombositopenia pada umumnya terjadi sebelum ada peningkatan hematokrit dan terjadi sebelum suhu turun. Jumlah trombosit $<100.000 / \mu$ l biasanya ditemukan antara hari sakit ketiga sampai ketujuh [2].

Secara praktis jumlah trombosit merupakan indikator penting pada penyakit Demam Berdarah. Salah satu obat herbal yang sudah ditemukan khasiatnya adalah daun ubi jalar. Menurut dr Arianto Djonosewodjo di RSUD Dokter Soetomo Surabaya, kandungan polifenol dalam daun ubi jalar dapat digunakan sebagai antioksidan untuk memperbaiki sistem kekebalan tubuh. Sistem kekebalan tubuh yang terdongkrak dapat menyebabkan tubuh mampu melawan virus [8].

Berdasarkan hasil penelitian Khaerani, dkk bahwa hasil pemeriksaan jumlah trombosit pada sampel darah mencit mengalami kenaikan sebesar $118 \%$ [4]. Infusa yang digunakan dalam penelitian sebelumnya adalah infusa daun ubi jalar merah, karena dari hasil penggunaan daun ubi jalar secara empiris menunjukkan perbaikan kondisi dan gejala pada pasien Demam Berdarah. Semua jenis ubi jalar dapat digunakan karena memiliki kandungan antioksidan walaupun setiap jenis ubi jalar tidak memiliki kandungan antioksidan yang sama.

Berdasarkan latar belakang tersebut maka peneliti tertarik untuk melakukan penelitian tentang Potensi Etnomedicine daun ubi jalar ungu (Ipomoea batatas L. Poir) Sebagai Obat Demam Berdarah di Sleman, DIY. Penelitian ini diharapkan dapat memberikan manfaat mengenai infusa daun ubi jalar ungu dan daun ubi jalar putih untuk meningkatkan jumlah trombosit sehingga dapat di jadikan sebagai obat Demam berdarah.

\section{Metode}

Penelitian ini merupakan penelitian true experimental design, dengan rancangan penelitian pre test and post test with control yang bertujuan untuk mengetahui gambaran jumlah trombosit sebelum dan sesudah pemberian infusa daun ubi jalar ungu dan ubi jalar putih dengan dosis 1,8 $\mathrm{ml} / 200 \mathrm{grBB} /$ hari; 3,6 ml/200 grBB/hari; dan 7,2 $\mathrm{ml} / 200 \mathrm{grBB} /$ hari.

Alat yang digunakan dalam penelitian ini adalah kandang hewan coba, alat Hematology analyzer, timbangan analitik, spuit, tabung mikrohematokrit, tabung mikro EDTA, hotplate, beaker gelas, batang pengaduk, gelas kimia, kain flanel dan cekok sonde. 
Bahan yang digunakan yaitu darah tikus putih, daun ubi jalar ungu, Anilin $10 \%$ dan akuades.

Persiapan atau adaptasi hewan uji tikus putih sebanyak 35 ekor selama 7 hari. Tikus putih dibagi menjadi 4 kelompok yaitu 1 kelompok kontrol dan 3 kelompok perlakuan. Sebelum perlakuan hewan uji diturunkan jumlah trombositnya melalui mekanisme kerusakan limpa dengan induksi anilin $10 \%$ secara intraperitoneal selama 3 hari dengan dosis $0,4 \mathrm{ml} / 200 \mathrm{grBB} /$ hari.

Perlakuan diberikan dengan memberikan infusa daun ubi jalar ungu atau putih sesuai perlakuan dengan dosis 1,8 ml/200 grBB/hari (ringan); 3,6 $\mathrm{ml} / 200$ grBB/hari (sedang); dan $7,2 \mathrm{ml} / 200$ grBB/hari ( berat) selama 7 hari.

Pengambilan spesimen darah tikus putih melalui sinus orbitalis menggunakan mikrohematokrit. Pengambilan darah tikus putih dilakukan sebanyak 2 kali yaitu sebelum pemberian infusa dan (pretest) dan sesudah pemberian infusa (postest). Kemudian spesimen darah dihitung jumlah trombositnya menggunakan alat Hematology analyzer.

\section{Hasil}

Hasil penelitian pemeriksaan jumlah trombosit pada tikus putih sebelum dan sesudah pemberian infusa daun ubi jalar ungu disajikan dalam bentuk grafik yang dapat dilihat pada Gambar 1 .

Berdasarkan hasil penelitian diperoleh tidak terjadinya peningkatan pada kelompok perlakuan
1, namun terjadi peningkatan pada kelompok perlakuan 2 yaitu $94 \%$ dan pada kelompok perlakuan 3 yaitu 224\%. Hasil uji statistik menunjukkan nilai $Z$ di dapatkan sebesar $-0,597$ dengan $p$ value (Asymp. Sig 2 tailed sebesar 0,550 dimana lebih dari batas kritis penelitian 0,05 sehingga keputusan hipotesis adalah menolak $\mathrm{H} 1$ yang berarti tidak terdapat perbedaan bermakna antara kelompok pre test dan post test jumlah trombosit tikus putih dengan pemberian infusa daun ubi jalar ungu.

Kelompok tikus putih perlakuan satu sesudah pemberian daun ubi jalar putih mengalami penurunan trombosit dengan rata-rata 382,6 (ribu/ $/ \mathrm{mm}^{3}$ ) atau $34,69 \%$. Kelompok tikus putih perlakuan dua mengalami penurunan jumlah trombosit dengan rata-rata $460,6\left(\mathrm{ribu} / \mathrm{mm}^{3}\right)$ atau $31,51 \%$, sedangkan kelompok tikus perlakuan tiga mengalami peningkatan jumlah trombosit dengan rata-rata 159 (ribu/ $\mathrm{mm}^{3}$ ) atau 26,45\%, namun peningkatan jumlah trombosit kurang dari peningkatan pada kelompok kontrol dengan jumlah rata-rata 289 (ribu/ $/ \mathrm{mm}^{3}$ ) atau 42,99\% Gambar 2.

Hasil uji statistik diperoleh nilai Z sebesar -2,277 dengan $p$ value (Asymp. Sig 2 tailed) sebesar 0,023 dimana kurang dari batas kritis penelitian 0,05 sehingga keputusan hipotesis adalah menerima $\mathrm{H} 1$ yang berarti terdapat perbedaan bermakna antara kelompok pre test dan post test jumlah trombosit tikus putih dengan pemberian infusa daun ubi jalar putih.

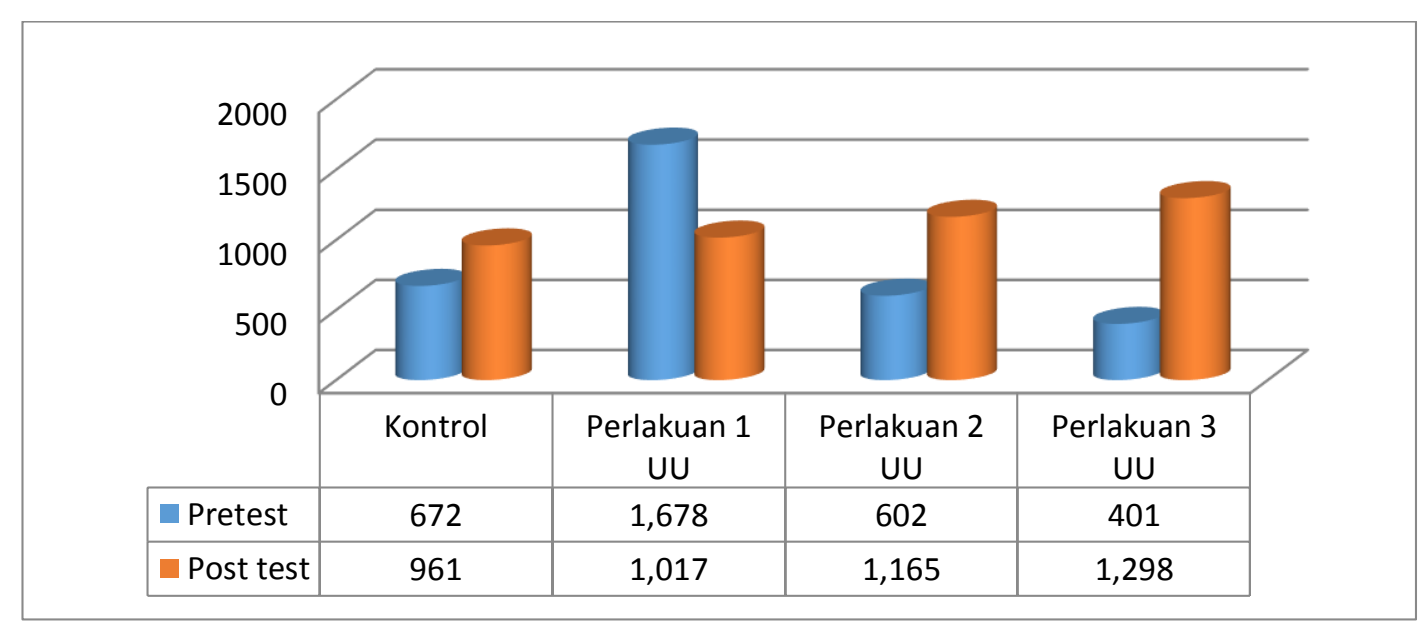

Gambar 1 | Grafik rata-rata jumlah trombosit tikus putih sebelum dan sesudah perlakuan dengan infusa daun ubi jalar ungu 


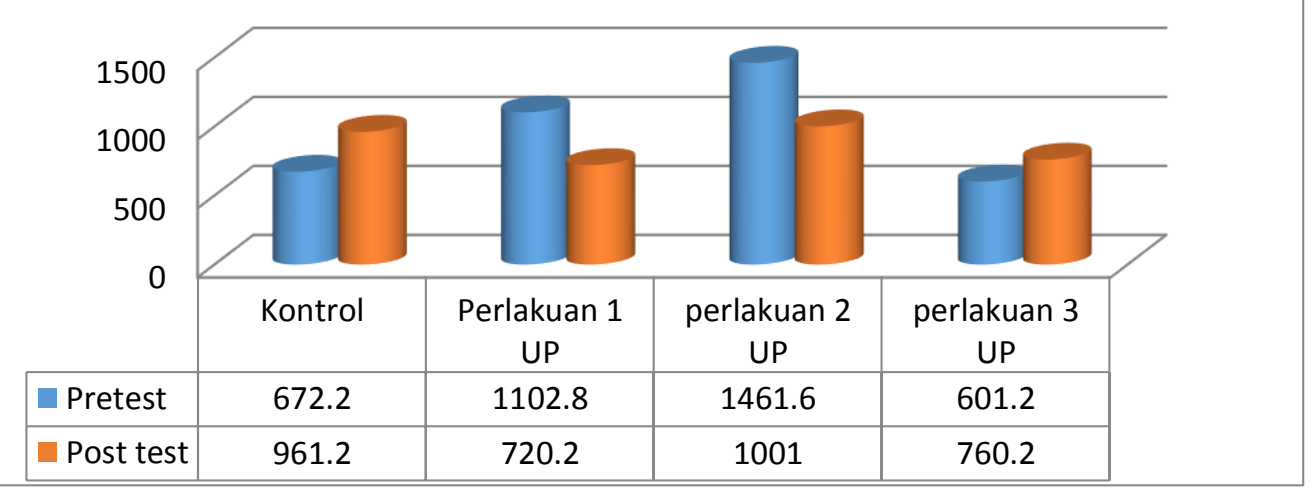

Gambar 2 | Grafik rata-rata jumlah trombosit tikus putih sebelum dan sesudah perlakuan dengan infusa daun ubi jalar putih

\section{Pembahasan}

Pada penelitian ini mendapatkan hasil bahwa usia dan jenis kelamin tidak ada pengaruhnya terhadap kelompok intervensi dan kelompok kontrol karena kedua kelompok berasal dari sampel yang homogen.

Berdasarkan hasil penelitian yang telah dilakukan diperoleh hasil terjadi peningkatan jumlah trombosit tikus putih sesudah pemberian infusa daun ubi jalar ungu pada dosis sedang dan tinggi sedangkan pemberian infusa ubi jalar putih terjadi peningkatan pada dosis tinggi.

Tikus putih yang digunakan untuk penelitian adalah tikus putih yang berjenis kelamin jantan karena yang betina mengalami masa datang bulan dan berpengaruh terhadap proses metabolisme yang dikhawatirkan dapat mempengaruhi hasil penelitian. Usia tikus putih yang digunakan adalah 2 bulan yang dikategorikan sebagai umur tikus dewasa, dan memiliki metabolisme tubuh yang masih bagus [5].

Tikus putih sebelum digunakan untuk penelitian diadaptasikan terlebih dahulu selama 7 hari untuk menyesuaikan diri dengan lingkungannya dengan diberi makan dan minum secara teratur. Hewan ini diberi infusa daun ubi jalar sesuai dengan perlakuan yang sudah ditentukan selama 7 hari.

Darah tikus putih diambil melalui sinus orbitalis pada bagian sudut mata. Pengambilan darah pada bagian ini lebih mudah, dan meminimalisir kemungkinan darah lisis pada saat pengambilan. Pengambilan darah melalui sinus orbitalis sering dilakukan untuk penelitian yang menggunakan desain pre dan post test. Sampel darah yang baik digunakan untuk pemeriksaan adalah tidak lisis, perbandingan darah dan antikoagulan sama, pemeriksaan darah tidak boleh lebih dari 1 jam setelah pengambilan. Penelitian ini menggunakan metode hematology analyzer karena alat ini membutuhkan waktu yang singkat untuk pemeriksaan, sampel yang digunakan sedikit, dan hasil lebih akurat. Prinsip kerjanya adalah flowcytometri dan impedansi [3].

Tikus putih kelompok perlakuan yang diturunkan trombositnya dengan diinduksi anilin diberi pakan dan minuman standar dan kelompok perlakuan diberi infusa daun ubi jalar ungu dengan dosis yang sudah ditentukan selama 7 hari. Kelompok kontrol (tanpa perlakuan) diberi pakan dan minuman standar tetapi tidak diberi infusa daun ubi jalar ungu. Hal ini berfungsi untuk mengetahui perbedaan peningkatan jumlah trombosit pada kelompok kontrol yang hanya diberi pakan dan minuman standar dengan kelompok perlakuan yang diberi pakan standar, minuman, dan infusa daun ubi jalar ungu.

Pemberian larutan anilin dalam penelitian ini dimaksudkan agar terjadi penurunan jumlah trombosit, karena ketika trombosit dalam keadaan normal kemudian diberi infusa daun ubi jalar maka tidak terjadi peningkatan yang signifikan. Pada saat tikus mengalami trombositopenia kemudian diberi infusa daun ubi jalar yang mengandung antioksidan maka akan terjadi peningkatan jumlah trombosit yang signifikan. 
Pemberian infusa daun ubi jalar dengan dosis ringan tidak menunjukkan peningkatan jumlah trombosit justru sebaliknya sehingga tikus pada kelompok perlakuan 1 terlihat kurang aktif dibandingkan kelompok perlakuan 2 dan 3. Hal ini diduga karena tikus putih pada kelompok perlakuan 1 yang diberi dosis sedang sebelumnya sudah mengalami trombositosis sehingga setelah diberi infusa senyawa polifenol, flavonoid dan tanin yang terkandung dalam infusa hanya memperbaiki sel-sel yang rusak dan menyebabkan trombosit pada kelompok perlakuan 1 menjadi normal.

Pemberian infusa dengan dosis sedang dan berat menunjukkan peningkatan jumlah trombosit yang signifikan dibandingkan kelompok kontrol. Kelompok perlakuan 2 yang diberi infusa dengan dosis sedang mengalami peningkatan sebesar $94 \%$ dan kelompok perlakuan 3 yang diberi dosis berat mengalami peningkatan sebesar $224 \%$. Hal tersebut karena tikus diberi infusa yang mengandung senyawa polifenol, flavonoid, dan tanin yang memiliki aktivitas dalam meningkatkan trombosit sedangkan kelompok kontrol hanya diberikan pakan standar AD II.

Daun ubi jalar ungu diduga memiliki antioksidan yang lebih tinggi dibandingkan daun ubi jalar putih. Daun ubi jalar ungu dapat memberikan regenerasi sel-sel baru yang baik. Hasil penelitian menunjukkan adanya peningkatan jumlah trombosit pada perlakuan dengan infusa daun ubi jalar ungu lebih baik di bandingkan dengan perlakuan infusa daun ubi jalar putih. Hal tersebut karena antioksidan dimiliki oleh daun ubi jalar ungu memiliki aktivitas dalam meningkatkan jumlah trombosit terutama senyawa polifenol, flavonoid dan tanin yang mampu bekerja secara sinergis dalam meningkatkan jumlah trombosit. Polifenol, flavonoid dan tanin memiliki aktivitas meningkatkan trombosit melalui mekanisme rangsangan terhadap GM-CSF (granulocyte macrophage colony-stimulating factor) dan IL-3 (Interleukin-3) GM-CSF dan IL-3 adalah sebuah hormon yang berfungsi untuk memicu pembentukan sel megakariosit. Dengan meningkatkan megakariosit dari stem sel dan proses maturasi megakariosit menyebabkan trombosit mengalami peningkatan yang signifikan pada kelompok perlakuan dengan pemberian infusa dibandingkan dengan kelompok kontrol yang tidak diberi perlakuan.

\section{Kesimpulan}

Penelitian menunjukkan bahwa pemberian infusa daun ubi jalar ungu dosis sedang dan tinggi dapat meningkatkan persentase jumlah trombosit pada tikus putih, sedangkan infusa daun ubi jalar putih hanya dapat meningkatkan persentase jumlah trombosit pada tikus putih pada dosis tinggi.

Pemberian infusa daun ubi jalar ungu sebelum dan sesudah perlakuan tidak memberikan perbedaan yang bermakna namun pemberian infusa daun ubi jalar putih memberikan perbedaan yang bermakna.

Infusa daun ubi jalar ungu mampu meningkatkan jumlah trombosit yang lebih banyak dibandingkan dengan infusa daun ubi jalar putih.

Sehingga dapat disimpulkan bahwa Infusa daun ubi jalar ungu dan ubi jalar putih memiliki potensi etnomedicine sebagai obat demam berdarah di Sleman, DIY.

\section{Apresiasi}

Peneliti mengucapkan terimakasih kepada Ristekdikti yang telah mendukung terselenggaranya penelitian ini melalui program hibah dikti 2017.

\section{Bibliografi}

1. Aminudin. 2009. Kiat Praktis Seputar Kesehatan. CV. Putra Setia, Bandung: 49-52.

2. Ariani, PA. 2016. Demam Berdarah Dengue (DBD). Nuha Medika, Yogyakarta: 1-3, 9.

3. Gandasoebrata. 2007. Penuntun Laboratorium Klinik. Dian Rakyat, Jakarta:19.

4. Khaerani, Barium H, dan Nonci FY. 2014. Efektivitas Infusa Daun Ubi Jalar (Ipomea batatas L) Terhadap Peningkatan Trombosit Pada Mencit (Mus musculus). Jurnal Jurusan Farmasi FIK. Vol. 2 No. 1.

5. Prasetya, H. 2012. Peluang Jitu Beternak Tikus Putih. Baru Press, Yogyakarta: 1-2, 40, 53.

6. Rukmana, R. 1997. Ubi Jalar Budi Daya dan Pascapanen. Kanisius. Yogyakarta

7. Wasito, H. 2011. Obat Tradisional Kekayaan Indonesia. Graha IImu, Yogyakarta: 11-12, 18. 
8. Widyastuti, R. 2016. Pengaruh Pemberian Air Rebusan Daun Ubi Jalar (Ipomea batatas) Terhadap Peningkatan Jumlah Trombosit Mencit (Mus musculus). The Journal Muhammadiyah Medical Laboratory Technologist. Vol. 2 No. 2 ISSN 2597-368 